\title{
Food, farming and trade on the Danube frontier: plant remains from Roman Aelia Mursa (Osijek, Croatia)
}

\author{
Kelly Reed ${ }^{1}$ (i) $\cdot$ Tino Leleković $^{2} \cdot$ Lisa Lodwick $^{3}$ (i) $\cdot$ Rhona Fenwick $^{4} \cdot$ Ruth Pelling $^{5}$ (i) $\cdot$ Helmut Kroll $^{6}$ (i)
}

Received: 4 June 2021 / Accepted: 10 September 2021 / Published online: 27 October 2021

(C) The Author(s) 2021

\begin{abstract}
Archaeobotanical investigations at the Roman town of Aelia Mursa, located near the Danube frontier in modern day Croatia, have revealed an extraordinary assemblage of food remains from a series of pits dated to the early 2nd century AD. The site yielded a wide array of economically important food remains, including staples such as Hordeum (barley), Panicum miliaceum (broomcorn millet), Triticum aestivum (bread wheat), Secale cereale (rye), Lens culinaris (lentil) and Vicia faba (broad bean). We also found a range of fruits, nuts, herbs and vegetables, such as Daucus carota (carrot), Cichorium intybus (chicory), Allium sativum (garlic), Ficus carica (fig), Vitis vinifera (grape) and Olea europaea (olive). Further, we found clearly identifiable remains of eggshell, fish bones and scales, unidentifiable fruit flesh and porridge or bread remains, as well as possible animal dung. The site provides important evidence of exotic foods including Piper nigrum (pepper), Oryza sp. (rice) and Punica granatum (pomegranate). This diverse and unique assemblage provides a tantalising insight into the character of food, farming and trade of the people living on the frontier of the Roman Empire.
\end{abstract}

Keywords Luxury food $\cdot$ Exotics $\cdot$ Archaeobotany $\cdot$ Roman military $\cdot$ Roman colony

\section{Introduction}

The Roman town of Aelia Mursa, in present-day Osijek, Croatia (Fig. 1), was founded by Emperor Hadrian as a colonia or veteran colony around AD 133 as recorded by an inscription (CIL III 3280, Suic 1985, p. 60). The colony was established on the site of an Iron Age settlement that probably came under Roman rule shortly

Communicated by S.M. Valamoti.

Kelly Reed

kellyreed@hotmail.co.uk

1 Oxford Martin School, University of Oxford, 34 Broad St, Oxford OX1 3BD, UK

2 Croatian Academy of Sciences and Arts, Trg Nikole Šubića Zrinskog, 11, 10000 Zagreb, Croatia

3 School of Archaeology, University of Oxford, 36 Beaumont St, Oxford OX1 2PG, UK

4 School of Social Science, The University of Queensland, Michie Building \#9, Level 2, St Lucia, QLD 4072, Australia

5 Historic England, Fort Cumberland, Fort Cumberland Road, Portsmouth P04 9LD, UK

6 Projensdorfer Str. 195, 24106 Kiel, Germany after the Pannonian War (13-9/8 BC). No military camp has been identified so far and archaeological finds show continuity in settlement occupation during this transition period (Leleković 2020; Tonc and Filipović 2020). Once brought under Roman rule, the town undoubtedly became an important commercial, administrative and religious centre in southern Pannonia due both to its proximity to the border of the Roman Empire, the Danube Limes, and its connection to a series of important imperial road and river networks (Domić Kunić 2012, pp 37, 44; see also Pinterović 1978; Fulford 1992). It is thought that Aelia Mursa was the last colony founded ex nihilo in the history of the Roman Empire (Mócsy 1974, p. 119; Leleković 2020, pp 79-81) and it was probably created with the aim of integrating and growing this undeveloped area of the Empire. Remains of bricks with the stamps of the legions legio II, legio VII and the cohort cohors VII Breucorum and a commemorative inscription of the legio II Adiutrix indicate significant imperial investment and subsidies for the construction of the colony (Leleković in press). Many of the veterans of the legions of Pannonia Inferior probably settled in the town and upon retirement they would have received either a piece of land (missio agraria) or a cash payment (missio nummaria) to start their civilian life 


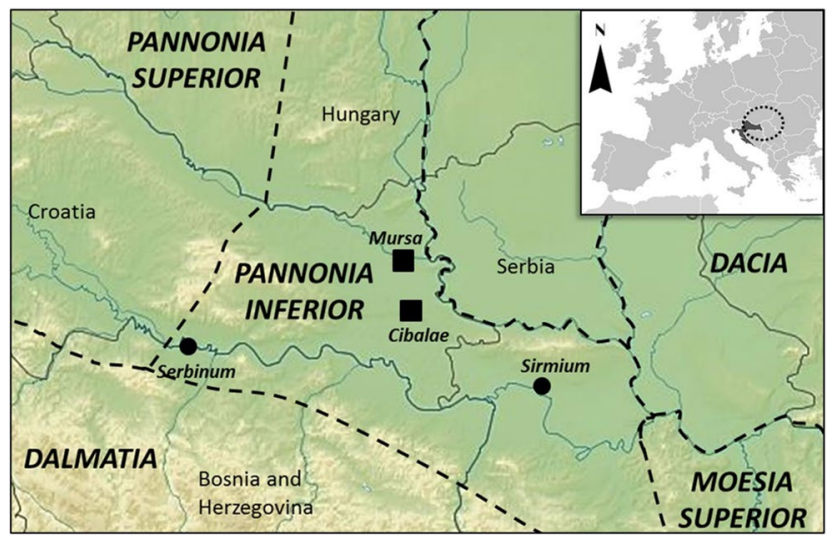

Fig. 1 Map of southern Pannonia, including the location of Aelia Mursa (Mursa)

(Wesch-Klein 2007, p. 439). Thus, in its early days Aelia Mursa probably had a strong military flavour, acting as a conduit for trade between civilian settlements and the military frontier (Reed and Leleković 2019).

What we know about diet and subsistence in southern Pannonia during the Roman period is limited. To date, archaeobotanical remains have only been recovered from four sites in eastern Croatia: Vitrovitica Kiškorija (Šoštarić et al. 2015); Osijek-Silos (Starčević 2010; Reed et al. 2019); Sćitarjevo and Illok (Šoštarić et al. 2006). Most of the plant remains are largely associated with agriculture, such as cereals, pulses and weed seeds, while only a small number of Mediterranean imports have been found, including Ficus (fig) and Olea (olive) (Šoštarić et al. 2006). Among the pottery dating to the 1st and 2nd century from Aelia Mursa there were amphorae, terra sigillata (fine red pottery) and thin-walled pottery from Transpadanian workshops in Lombardy testifying to the strong connections with northern Italy (Leleković 2018; Tonc and Filipović 2020). A fragment of a Dressel 6B amphora carrying the letters CRISPINI(I), indicating a workshop in Loron, near Poreč, Istria, suggests the storage and transport of olive oil to the town in the 1st century AD (Tonc and Filipović 2020). Fragments of Beltrán IIA, used for fish products (garum) and Dressel 2-4 amphorae, used primarily for wine, have also been found in the early levels of Aelia Mursa (Brukner 1981). Although only a relatively small number of amphorae have been recovered overall, they show the early imports of commodities from other regions of the Roman Empire.

This paper adds to this limited dataset by presenting the archaeobotanical remains collected from pits excavated in 2014-15 at Park Kraljice Jelene Kosače, Osijek (OS-KOS). The remains provide important insights into the diet and subsistence of Roman Aelia Mursa during the early days after its founding in the 2 nd century AD.

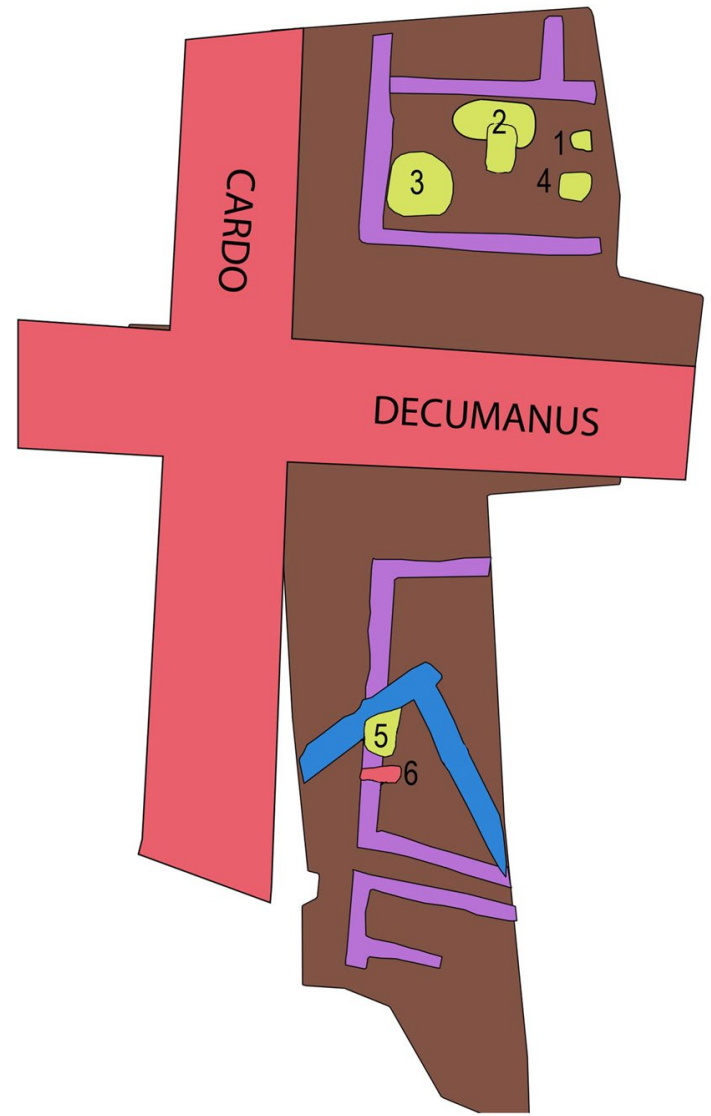

Fig. 2 Plan of the excavation at Park Kraljice Katarine Kosače (OSKOS), showing locations of pits 1-6. Cardo, North-South street; decumanus, East-West street

\section{The site}

During excavations at Park Kraljice Katarine Kosače, two large pits and two smaller pits were discovered in the first colonial layer (ca. AD 130) in the northern part of the trench (Fig. 2). These were probably originally located within an enclosed backyard of a large wooden building comprising part of the town block, Insula A. The building seems to have burnt down, which subsequently sealed the pits. The most significant excavated feature was Pit 3 , which was $4.5 \times 4 \mathrm{~m}$ wide $\times 3.5 \mathrm{~m}$ deep and contained several different backfills (SUs 382, 387, 388, 391) which were sampled (Fig. 3; ESM Table Insula A). Archaeological finds included a large collection of potsherds of cooking and table ware, animal bones and a small number of iron and copper alloy objects. Pit 2, located northeast of Pit 3, was slightly smaller, with two layers (SU 360 and $386)$ at $2 \times 1.3 \mathrm{~m}$ wide $\times 1.4 \mathrm{~m}$ deep. The fill consisted of mixed burnt debris and large numbers of pottery fragments, including a well-preserved upper part of a Beltrán IIA amphora. This type was usually used to contain a 
Fig. 3 Cross section of the excavation at OS-KOS showing pits and their stratigraphic units; right: pit 4; middle: pit 2; left: pit 3

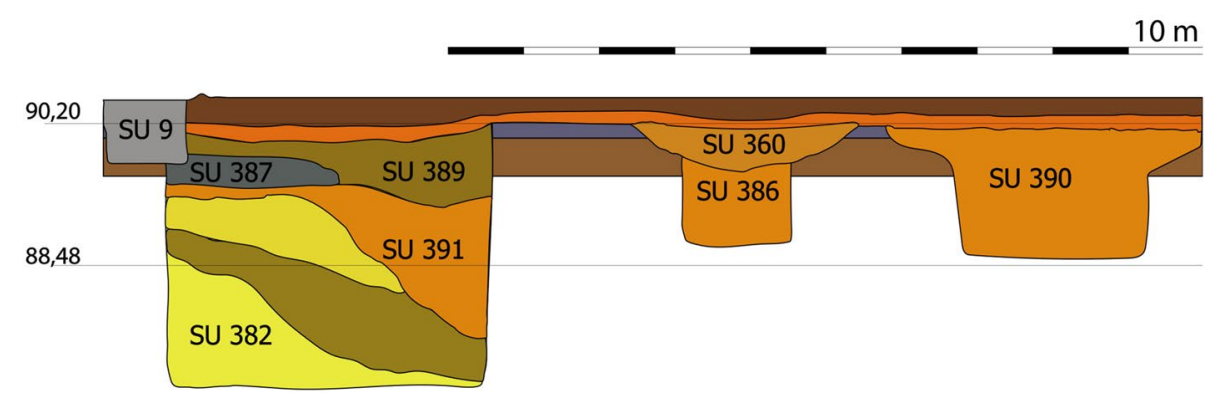

range of fish-based products and has been found distributed across the Danube region until the mid 2nd century AD (Bezeczky 1996; van Neer et al. 2010). Sherds of the same amphora were found in Pits 2 and 3, indicating that they were both simultaneously filled with rubbish and debris. SU 360 was a shallow upper layer of pit 2 measuring, $6 \times 2 \times 0.4 \mathrm{~m}$ and had a similar backfill to SU 386, with pottery, metal and animal bone finds, but it was difficult to distinguish how it linked with the other SUs. Two further pits, Pit 1 (with SU 350, not shown) and Pit 4 with a single unit (SU 390), were located close together in the north-eastern part of the trench. The pits were oval with similar dimensions, $1.5 \times 1.5 \times 1.3-1.4 \mathrm{~m}$ and were filled with pottery, some charcoal and evidence of burnt soil.

Current interpretations of this part of Insula A suggest an area associated with food preparation, determined from the significant quantities of well-preserved ceramic kitchen and table wares, animal bones and archaeobotanical remains (Reed and Leleković 2019). Only a few sporadic finds relate to other aspects of everyday life, so the excavated pits and debris from the possible burned wooden structure were probably in a backyard attached to a kitchen of a large house or tavern. It is unclear what exactly the pits were used for, but they could have included latrine waste, domestic rubbish and/or other waste.

In the southern part of the excavation in 2014 another town block (Insula B) was excavated. Here two features (SU 383 and SU 385, ESM Table Insula B), also dating to the first colonial layer of the site, were sampled for archaeobotanical remains. Pit 5 (SU 383) was a shallow hole that could have been used to backfill and level part of Insula B. The fill contained charcoal and ash inclusions along with a large amount of pottery and animal bones, indicating that it was probably filled with domestic rubbish. Beside this feature was Pit 6 (SU 385), which may represent a pit or part of a ditch. The fill here was similar to those of Insula A, with burnt orange soil, pottery and small numbers of metal and glass objects.

\section{Materials and methods}

From Insula A, ten soil samples were collected from four pits, while eight samples were collected from two pits in Insula B (ESM). Judgement samples were collected, however, the precise sample volumes were not recorded, but they were estimated to be roughly $20-30 \mathrm{~L}$. The samples were processed on site by bucket flotation and sieved using a $500 \mu \mathrm{m}$ mesh. The resulting flots were sorted and analysed at the University of Oxford, UK, and the University of Queensland, St Lucia, Australia, using stereo zoom microscopes with $7 \times$ to $45 \times$ magnification.

Identifications were made using the modern reference collection held at Fort Cumberland Laboratories, Historic England, the Institute of Archaeology at University College London, and the archaeology laboratory at the University of Queensland, as well as with reference to the seed atlases of Bojňanský and Fargašová (2007) and Cappers et al. (2006), and the cereal identification guide of Jacomet (2006). The nomenclature of scientific plant names follows Zohary and Hopf (2000) for cultivars and the Flora Croatica Database (Nikolić 2018) for wild plants. A standardised counting method was used, whereby each grain counts as one and minimum number of individuals (MNI) was estimated for fragments of grains. Glume base fragments were counted as one unless clearly representing part of another fragment, while whole spikelet forks were counted as two glume bases. The fruit and weed seeds were counted as one, even when only a fragment was found, except where large seeds were broken and clearly represented the same parts of the same one for example, Cornus mas, Quercus sp. 


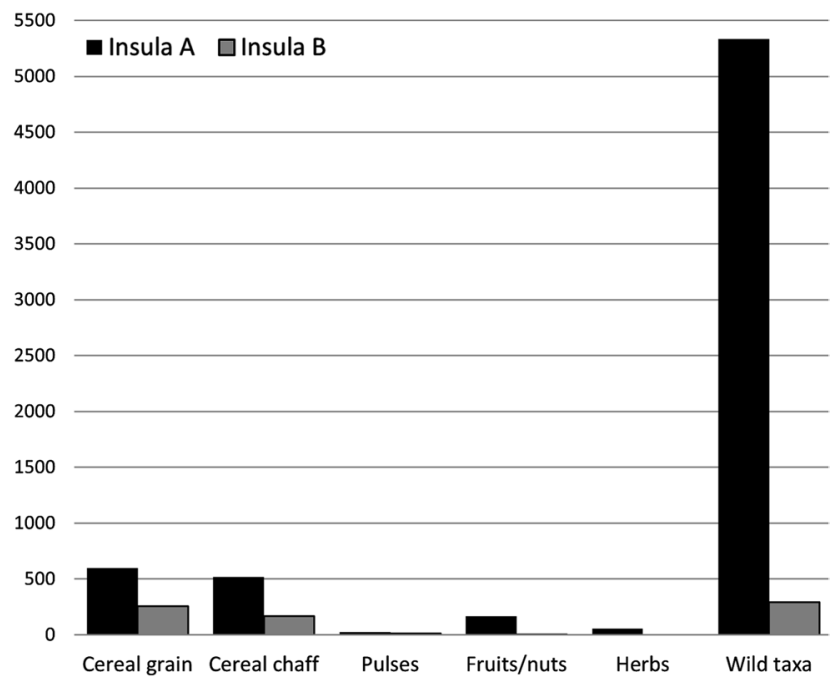

Fig. 4 Quantity of carbonised remains per category for Insulae A and $\mathrm{B}$, OS-KOS

\section{Results}

A total of 8,193 whole or fragmentary seeds, fruits and nuts were recovered from the 18 samples collected from the four pits (ESM). Most of these remains were carbonised, although seeds of one taxon, Sambucus nigra L. (elder), were found non-charred. Of the 7,484 seeds identified from Insula A, about $75 \%$ were represented by wild taxa (Fig. 4), the vast majority of which were recovered from sample SU 391. Only 763 remains were identified from Insula B and these were dominated by cereal grain and chaff (c. 60\%) followed by wild taxa (ca. 37\%). For a relatively small number of samples the diversity was extremely high with around 116 different taxa identified to genus or species.

The main crop finds from OS-KOS were of cereals, representing at least eight cultivars. The most numerous, present in 15 of the samples, was Hordeum vulgare (barley), both hulled and naked type grains, as well as several barley rachis recovered particularly from SU 391. Twisted caryopses and diagnostic rachis remains suggest the presence of the sixrow variety. Also ubiquitous in 15 of the 18 samples was Triticum aestivum/durum (free-threshing wheat) and Panicum miliaceum (broomcorn millet). The presence of a few rachis nodes and internodes characteristic of the hexaploid subtype suggests that at least $T$. aestivum (bread wheat) was present. At least half the samples contained a few grains of T. dicoccum (emmer) and T. monococcum (einkorn), while T. spelta (spelt) grains were more difficult to determine, although eight glume bases were recovered from SU 391. Small quantities of Avena spp. (oat) and Secale cereale (rye) were found along with a small number of rye rachis fragments in SU 391. No oat florets were identified, so it is not
Fig. 5 Fruits and nuts from OSKOS, context SU 391; a Juglans sp. Nutshell, b Malus/Pyrus sp. pip, c Cucumis cf. melo seeds, d Quercus sp. cupule, e Punica granatum seed, f Oryza cf. sativa (rice) grain, scale bars: a, b, d, $5 \mathrm{~mm}$; c, e, f, $1 \mathrm{~mm}$
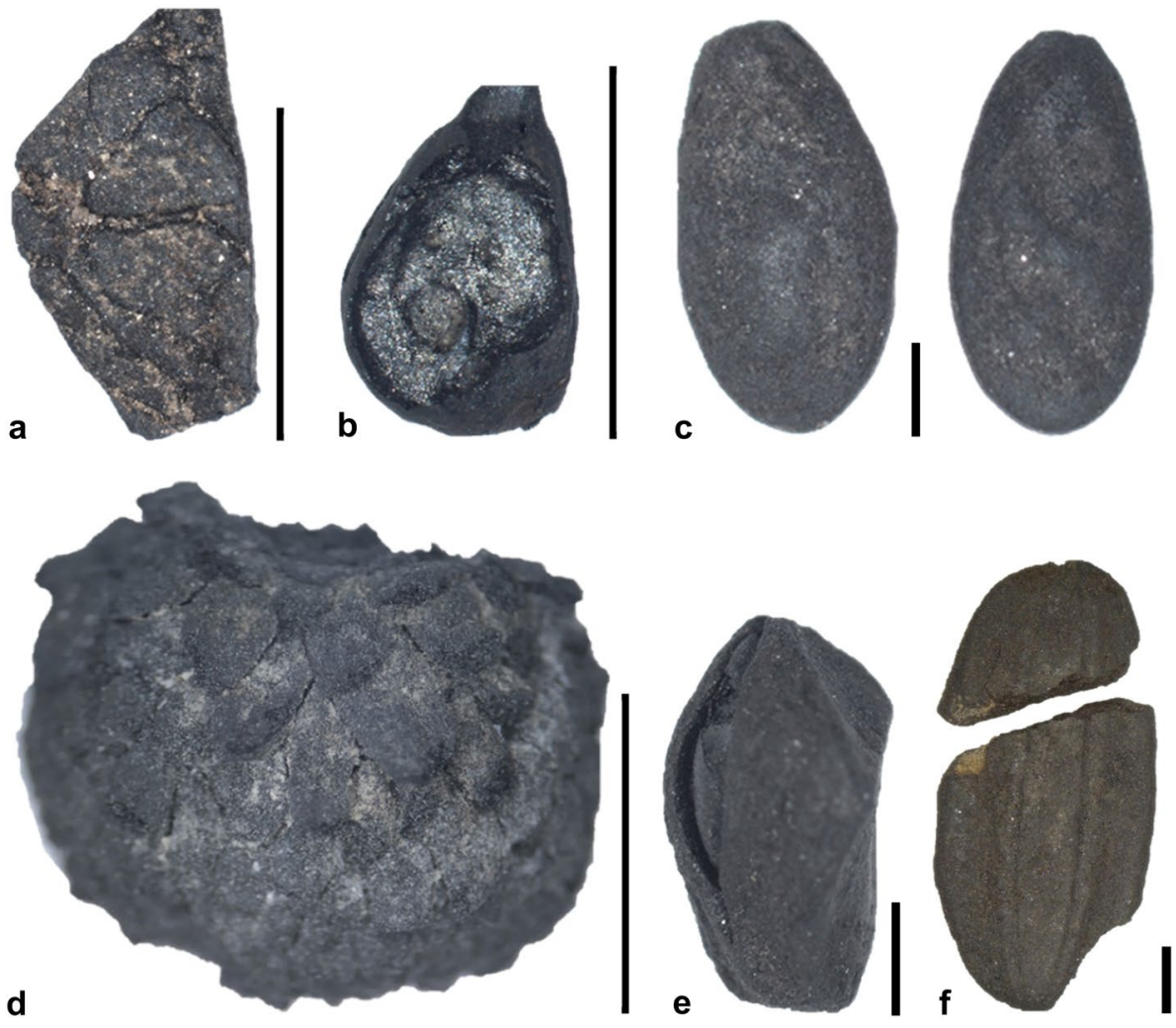
possible to determine whether the oats are wild or cultivated. A couple of grains of Oryza cf. sativa (rice, Fig. 5f) were also identified from SU 391 (Insula A) and one from SU 383 (Insula B). Overall, only a small number of chaff and straw fragments were found in the assemblage, except in SU 391.

Very few pulses were recovered, representing two main species, Lens culinaris (lentil) and Vicia faba (broad bean). This again could be a preservation issue, as pulses are commonly under-represented in assemblages. Similarly, fruit and nut remains were not common, except in SU 391 and SU 382. Feature SU 391 contained a large number of Ficus carica (fig) seeds and Vitis vinifera (grape) pips, as well as a wide range of other fruits including Olea europaea (olive), Prunus spinosa (sloe), Malus/Pyrus sp. (apple or pear), Cucumis cf. melo (possible melon), Fragaria vesca (strawberry), Rubus fruticosus (blackberry), R. idaeus (raspberry) and Physalis alkekengi (Chinese lantern). Sambucus nigra was found in an uncharred state from pits SU 360, SU 386 and in Area B, but it is possible that this is a modern contaminant. Small nutshell fragments were recovered from two taxa, Corylus sp. (hazel) and Juglans regia (walnut). Interestingly, half of a well-preserved Quercus (acorn) cupule was also recovered from SU 391 (Fig. 5d).

SU 391 also yielded several herbs including Cichorium intybus (chicory), cloves of Allium sativum (garlic), and seeds of Anethum graveolens (dill) and Daucus carota (carrot) (Fig. 6). One particularly striking find from SU 391 was of five peppercorns of Piper nigrum, two of which are similar to white pepper and three to black pepper (Fig. 6d, e). Both are the fruits of P. nigrum, but they are processed
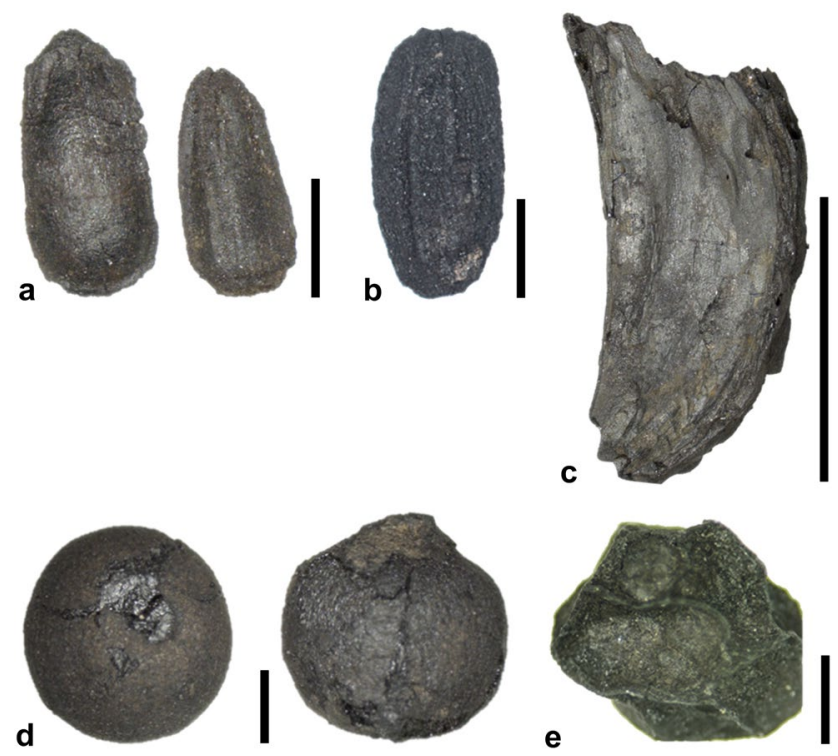

Fig. 6 Carbonised remains from SU 391, OS-KOS; a Cichorium intybus seed, b Daucus carota seed, c Allium cf. sativum, clove fragment, d Piper nigrum (white pepper) peppercorn, e P. nigrum (black pepper) peppercorns, scale bars: $1 \mathrm{~mm}, \mathrm{c}, 5 \mathrm{~mm}$ differently. White pepper berries are fully ripened when they are picked, and once processed by soaking fermenting and drying, the outer layer is removed. In contrast, black peppercorns are picked when almost ripe and sun-dried, turning the outer layer black. Here the black pepper has a distinct wrinkled appearance, while the white pepper is smooth, with slight radial veins and a small point at the apex and a small flat attachment scar at the base.

Over 100 different wild taxa were also present in the samples, with a few dominant ones. In Insula A, small legumes (Trifolium/Melilotus sp.) account for 30\% of the wild plants, represented by over 1,500 seeds, followed by Prunella vulgaris (self-heal) at $8 \%$ and Agrostemma githago (corncockle) at $5 \%$. Some of the other taxa, although present in smaller numbers, may have also had economic use. For example, Hyoscyamus niger (henbane), Malva sp. (mallow), Solanum nigrum (black nightshade) and Mentha sp. (mint) were used for either their medicinal or culinary properties. Insula B had a smaller quantity and diversity of wild plants, being largely dominated by small legumes and grasses. Several remains were not identified but were clearly either a fruit or seed head with identifiable characteristics (Fig. 7m, q).

Generally, the wild plants can be divided into five habitat groups, weeds of fields and gardens, weeds of ruderal places, grasslands, wetlands and ecologically indeterminate, although some can overlap these categories. For example, Chenopodium album, Bromus sterilis/tectorum, Galium aparine and Lapsana communis can be categorised as ruderals or woodland plants, as well as weeds of crops (Bakels 1999). Those identified to genus are also generally more difficult to allocate to a group. In some of the samples, there were plants that could be found as weeds in cultivated fields or gardens including Agrostemma githago, Brassica sp., Bromus arvensis/hordeaceus/secalinus, Fallopia convolvulus, Sherardia arvensis, Thlaspi arvense and Valerianella dentata. Additional ruderal plants include Verbena officinalis, Plantago major, Poa annua, Melilotus sp. and Picris hieracioides. Grassland plants include Ononis repens, Alopecurus pratensis, Phleum sp., Lolium sp., Plantago lanceolata, Poa sp., etc. There are also wetland plants in the assemblage, Alisma gramineum, Eleocharis palustris, Juncus sp., Iris spuria and Carex spp.

\section{Other types of remains}

As may well be expected from deposits of rubbish and possible latrine waste we found a wide array of economically important materials in the samples, including remains of eggshell, fish bones and scales, possible animal dung, unidentifiable fruit flesh and food remains such as bread- and porridge-like charred lumps. We also found a large amount of carbonized wood, twigs and buds, especially in Insula A. Initial analysis of the wood suggests the presence of Quercus 
Fig. 7 Carbonised wild plants from OS-KOS, remains are seeds where not otherwise stated; a unripe Vicia sp., b Valerianella dentata; c, Coronilla sp., d Trifolium/ Melilotus group, e Prunella vulgaris, $\mathbf{f}$ Alisma gramineum (embryo), g Echinochloa crusgalli, $\mathbf{h}$ Lapsana communis, $\mathbf{i}$ Juncus sp. seed pod, j Dianthus/ Petrorhagia sp., k Ranunculus acris, 1 Thymelaea passerine, m Asteraceae seed head, $\mathbf{n}$ Hyoscyamus niger, o Bromus secalinus/hordeaceus-type, $\mathbf{p}$ Adonis sp., q unknown seed pod or fruit, $\mathbf{r}$ Digitaria sanguinalis, $\mathbf{s}$ Arrhenatherum elatius, $\mathbf{t}$ Fabaceae seed pod, u Schoenoplectus sp., scale bars: $1 \mathrm{~mm}$
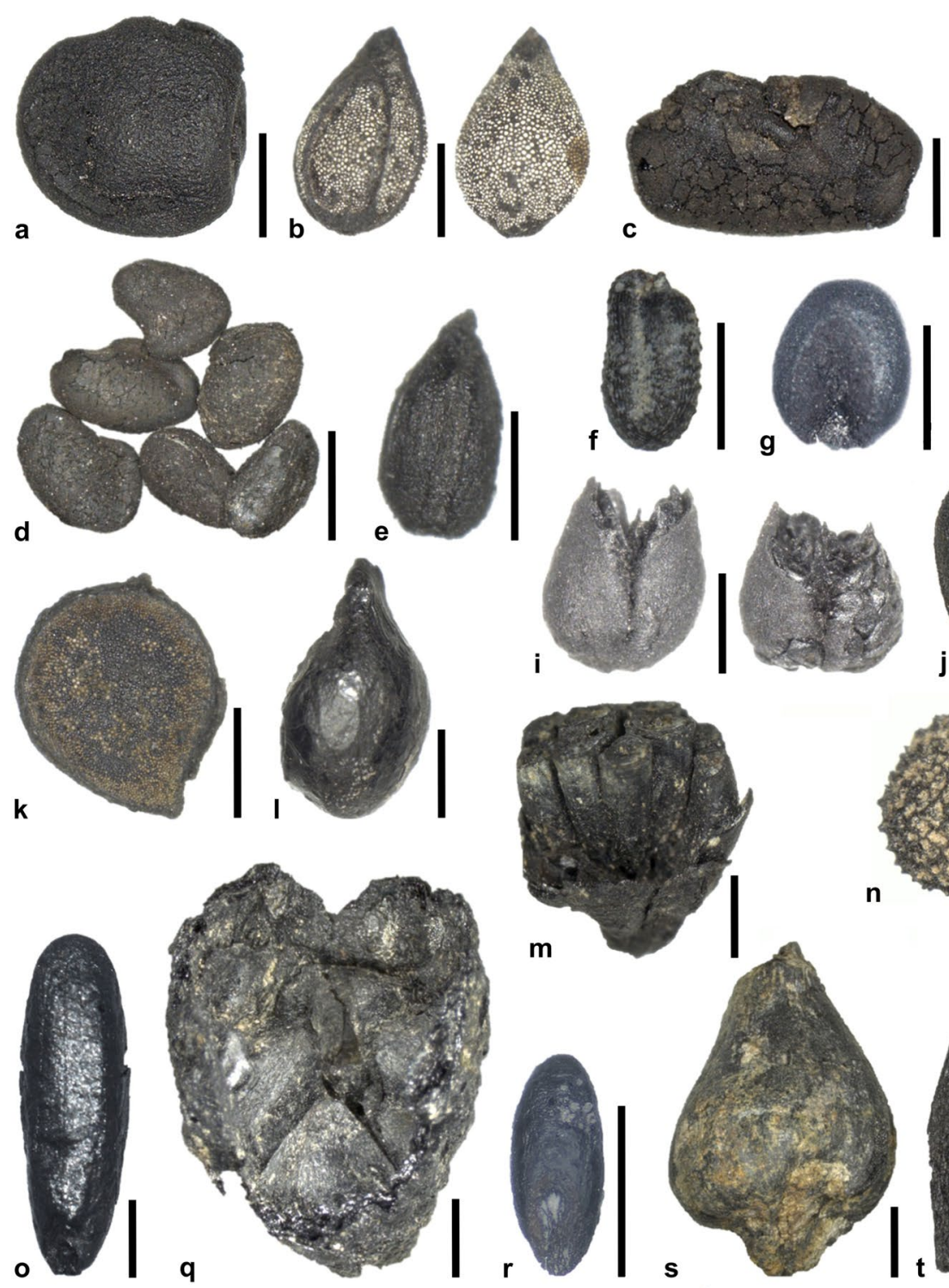

i
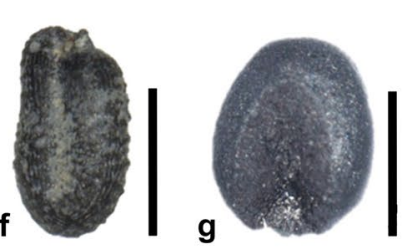

h
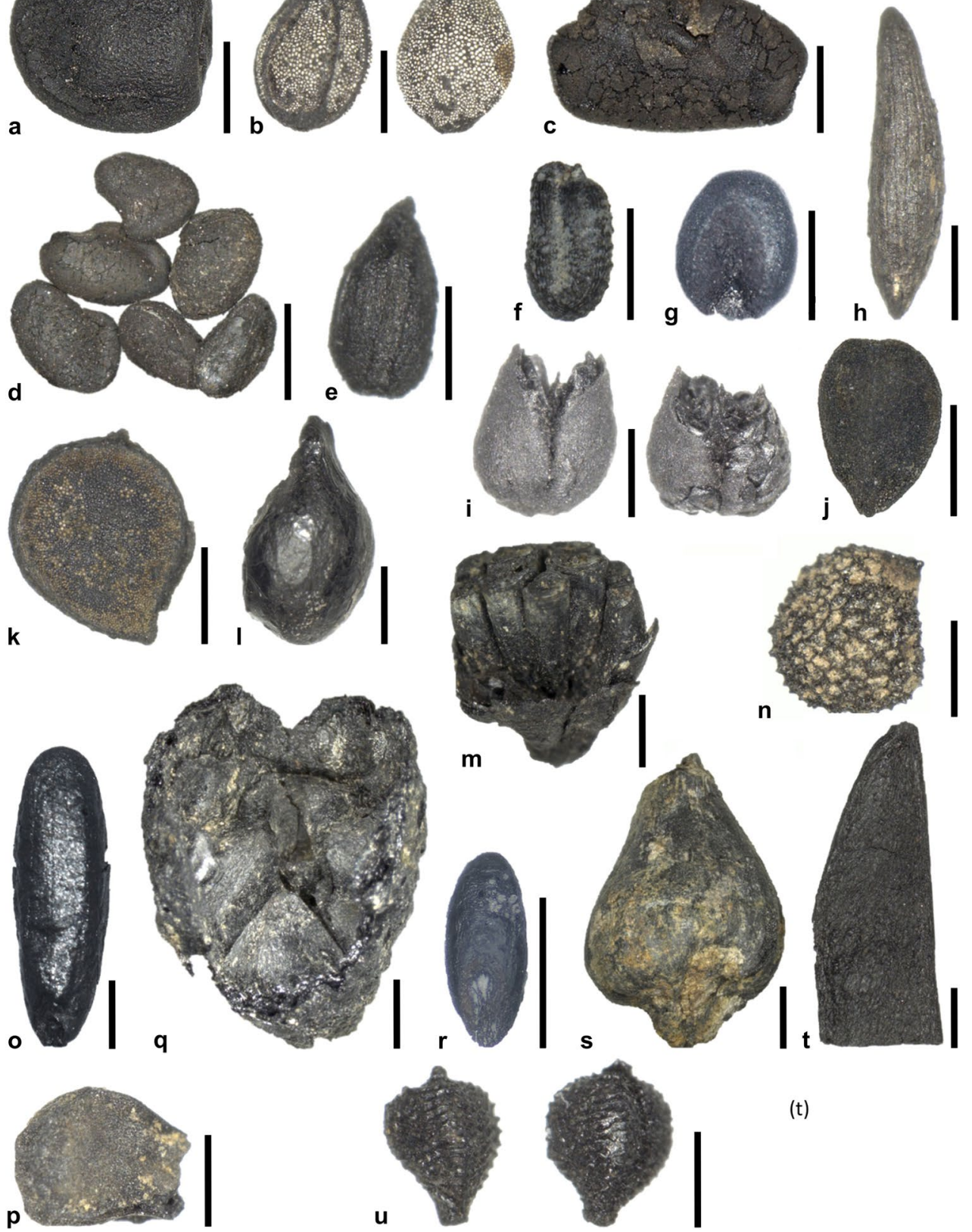

(t) (oak) as well as Salix (willow) buds, which could have been used in the construction of the buildings at Aelia Mursa in the early phases. Other carbonised lumps were also quite common, along with over 100 fragments that had grasslike impressions on the outside (Fig. 8a). Dung or possibly bread was tentatively identified from SU 391 (Fig. 8b), as well as carbonised fruit flesh and food remains, possibly bread or porridge, from both areas. The food remains had large closed voids and cracking (González Carretero et al. 2017), as well as clear evidence of bran and in some cases seeds or seed fragments (Fig. 8c, d). Identification of these carbonised remains awaits study with a scanning electron microscope (SEM).

A few eggshell fragments were recovered from both Insula A and B. Although not fully analysed, the eggshell fragments are extremely thin (Fig. 9a) and could fall within the range of domestic chicken or duck as the eggshells of these species measure between 0.32 and $0.4 \mathrm{~mm}$ thick (Sidell 1993). In addition, over 100 fish scales and five fish bones were recovered from Insula B (SU 385), while only one fish vertebra ( $3 \mathrm{~mm}$ in size) was identified from Insula A (SU 391). The majority of the fish scales (Fig. 9b) are of 
Fig. 8 Charred remains from SU 391, OS-KOS; a amorphous material with grass impressions, b dung/bread, c food remains, d food remains with seed inclusion, scale bars: a-c, $2 \mathrm{~mm}, \mathrm{~d}$, $1 \mathrm{~mm}$
Fig. 9 Remains from SU 391, OS-KOS; a eggshell, b fish scales, scale bars: a, $1 \mathrm{~mm}, \mathrm{~b}$, $2 \mathrm{~mm}$
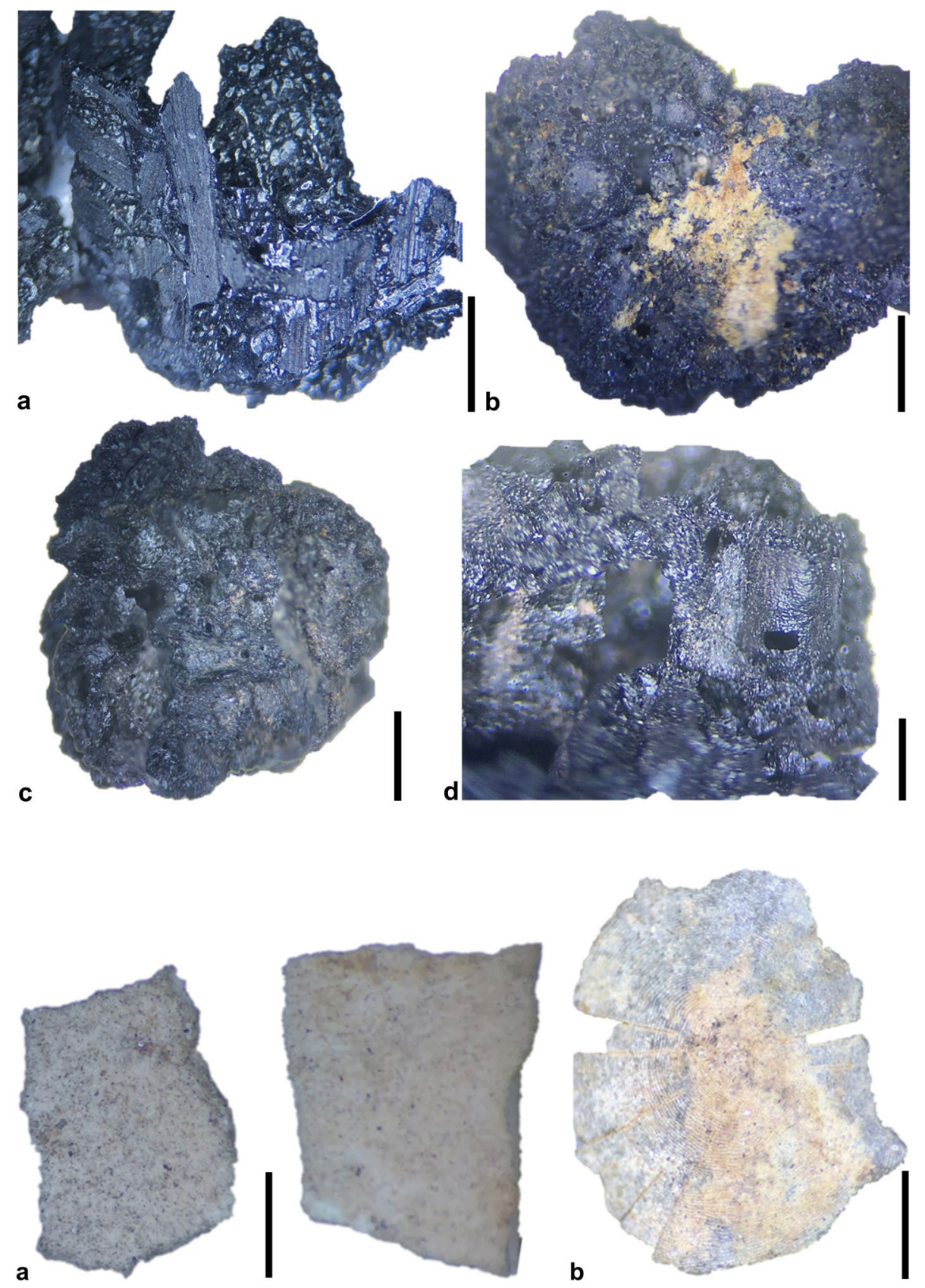

the cycloid type; typically a thin, smooth, disk-like structure which is more or less circular in outline, and is characteristic of the majority of fish such as herrings, trout, hake or sole (Casteel 1974). Unfortunately, considerable variation in scale shape and size, even between different areas of the same individual fish, mean that these are not always the best indicator for identification (Patternson et al. 2002). Both bones and scales are disrupted by heating, such as during cooking or prolonged immersion in a warm liquid, and by enzymes if eaten (Nicholson et al. 2018), thus their presence in relatively high numbers would suggest that they were discarded before the fish were cooked or consumed. To date, no further analyses have been conducted on the fish bones and scales recovered.

\section{Taphonomy}

Whether the pits were all open at the same time or sequentially filled is unclear, however the presence of sherds of the same amphora found in Pits 2 and 3 suggests that they were being filled simultaneously. What we suspect is that the pits were only in use for a short period, maybe 10 years, and became redundant as the new sewage system, which was built soon after Aelia Mursa became a colony, was 
connected to the buildings. The pits were then covered by a burnt layer, after it is assumed a nearby building must have burnt down and the debris was scattered across Insulae A and B. Thus, small patches of burnt clay and charcoal were observed in the upper layers of the pits. Yet, it is unclear whether any of this debris penetrated the pits, as all the pits contained charcoal to a greater or lesser extent.

Examining the samples per pit, we can see possible differences in the formation processes. Pits 1 (SU 350), 4 (SU 390), 5 (SU 383) and 6 (SU 385) represented possibly one fill episode, while Pit 2 (SU 360, SU 386) and 3 (SU 382, SU 387, SU 388, SU 389) had distinguishable layers of material (Fig. 2). Pits 1, 4 and 5 provided relatively small numbers of plant remains, made up predominantly of a few cereals and weeds. The remains are typical of crop processing waste that was charred and finally deposited in the pits (Jones 1992). Whether this was a deliberate depositional act, by dumping remains from a fire or sweeping general burnt debris into the pit is unclear. There are similar compositions of cereals and weeds in Pits 2 and 6, although Pit 6 also contained a few pulses and fruit remains. Pits 2, 5 and 6 also revealed high numbers of glume bases, supporting the theory that these remains came predominantly from crop processing waste.

The composition of Pit 3 is slightly different to the others. The various layers identified during the excavation probably indicate different depositional events. The density of remains is extremely high, especially in layer SU 391 (> 205 remains/L). The widest range of taxa comes from this pit, specifically layer SU 391, including cereals, pulses, fruits, herbs and exotics, as well as a huge amount of weed seeds, especially small legumes (Fig. 7). Preservation was also excellent, with evidence of pulse pod fragments (Fig. 7t), a Juncus sp. seed capsule with the seeds in situ (Fig. 7i), an Asteraceae flower head (Fig. $7 \mathrm{~m}$ ) and other identified articulated seeds within pods or fruit flesh (Fig. 7q). The preservation of these more delicate remains, which are more typically found at waterlogged sites (Lodwick 2020), would suggest primary deposition, and they were probably burnt in situ. As discussed already, some of the material could have come from crop processing waste. However, it cannot be ruled out that other activities may have occurred.

Crop by-products can be valuable material for feeding domestic animals (Foxhall 1998; Jones 1998; Derreumaux 2005). Although there is no evidence of keeping livestock in the town, the possible presence of dung in the samples may indicate a possible source for some of the weeds and chaff in these contexts. Distinguishing fodder and fodder remains from dung is, however, notoriously problematic (Spengler III 2019). Alternatively, the strong grassland component seen in Pit 3 may suggest remains of stable flooring (Lodwick 2017b), although not much straw or bracken was identified from the samples. Ruderal plants growing in the courtyard could have also been accidentally burnt and incorporated in the assemblages. Other sources for the wild plants and chaff/straw remains could have been associated with building materials (van der Veen 1999). As the first phase of the colony consisted of wooden buildings, the construction techniques were probably similar to past traditions of using wattle and daub. Thus, the walls could have been made from a mixed organic filler, using materials such as straw, chaff or hay (Šedo and Knápek 2016). Thus, rubbish from these activities may have been burnt within the courtyard or in the vicinity of Insula A and the remains swept into one or two of the pits.

Large amounts of charcoal were found in Pit 3, especially SU 391, and so another source of the remains could be from domestic hearths where general food waste could have been discarded, whether intentionally or accidentally, while cooking. The excellent preservation of some of the remains may indicate burning in situ, possibly latrine waste that was later burnt in the pit. Ritual offerings cannot be ruled out either, although if any were burnt and deposited in the pit they probably then become mixed with other rubbish making it impossible to distinguish them. Thus, it is likely that several sources account for the presence of these remains. Waste was a common problem in Roman Italy (Koloski-Ostrow 2015; Havlíček and Morcinek 2016) and others have also noted the multi-purpose use of pits, both for household and animal/human waste, that makes it hard to disentangle waste disposal practices (van Zweiten et al. 2017).

\section{Discussion}

The environmental finds from the pits discovered at OSKOS provide a unique snapshot of dietary customs of the population of Aelia Mursa around AD 130s. As may well be expected from deposits of rubbish and possible latrine waste there is a wide array of economically important materials in the samples. Interestingly the survival of fish scales could suggest that either fresh or dried fish was being processed at the site. Evidence of salted fish being transported in amphorae has also been found elsewhere, for instance from the Grado shipwreck in the northern Adriatic Sea (Auriemma 2000) and it cannot be ruled out here. The fact that these remains probably come from freshwater fish could suggest they were caught near the site in either the river Drava or the Danube. Evidence of eggshells may also indicate the keeping of hens nearby, although the shells could also have come from ducks or other wild birds. Several agricultural works provide instructions for the care of egg-laying chickens, including housing requirements and modifying feed to make hens lay sooner, more often, and with larger eggs (Columella, De Re Rustica VIII.3.1-8; VIII.5.1-2, Forster and Heffner 1954). 


\section{Local and regional crop production in southern Pannonia}

Cereals and pulses would have been dietary staples during the Roman period, providing a significant proportion of the calorific intake needed. The range of cereals identified at Aelia Mursa is comparable to those of other regions, including the military sites located along the Rhine, where up to AD 140 barley, emmer, spelt and bread wheat, millet, oats and rye were all found in varying quantities, as at Neuss (Knörzer 1970) and also in the Rhine delta (Cavallo et al. 2008, p. 75). Many of these crops, especially barley, wheats and millet were also grown in the region of southern Pannonia from prehistoric times (Reed 2016, 2020) and would have been a familiar part of the local crop production system. Evidence of chaff remains and possible cornfield weeds in the assemblage would also indicate local crop processing, even if only to a small extent within the settlement. Whether the inhabitants at this early stage of the colony were farming themselves in unclear, but it is likely that a portion of the cereal supply for the town came from local farmers in southern Pannonia (Reed and Ožanić Roguljić 2020). It is also unclear how each crop was perceived and used. For example, ancient sources have described instances where barley was given to soldiers as a punishment, yet archaeological evidence has started to contest this by showing that, at least in Britain, barley was consumed by soldiers (Britton and Huntley 2011).

The presence of these cereals also does not necessarily indicate their being grown solely for human consumption. Barley, for example, was used to feed horses (Wilmott 2001, p. 103; Vossen and Groot 2009), while Columella (De Re Rustica II.10.31, Ash 1941) reported that oats were, in some instances, cut for hay or fodder. Wheat, millet, peas and barley too are noted in ancient texts as feed for birds, such as fowl and pigeons. As already mentioned some of the wild plants recovered from Insula A may have come from stable flooring or from manure, possibly indicating foddering. In the Roman period large areas of marshland would have been located near Aelia Mursa and some suggest that horses and cattle can graze quite adequately in wet areas all year round (Vossen and Groot 2009). Although this is hard to determine, some of the remains could indicate dung from local grazing, especially as there are wetland and meadow plants in the assemblage.

In addition to cereals and pulses, we also found a range of fruits, nuts, herbs and vegetables, many of which, according to ancient sources, could have been used for either food or
Table 1 Examples of plants found at OS-KOS recorded as economic taxa in Roman sources and their uses

\begin{tabular}{llll}
\hline Species & Food & Med. & Sources \\
\hline Allium sativum & R & & Plin.Nat.19.34; Cels.2.18, 2.21-22 \\
Anethum graveolens & LS & Plin.Nat.19.52; Cels.2.21, 2.29 \\
Atriplex/Chenopodium & L & & Plin.Nat.19.35-37, 20.83 \\
Corylus avellana/C. maxima & F & & Plin.Nat.15.24; Cels.18.6; Virg.G.2.299 \\
Cucumis sativus & F & S & Plin.Nat.19.23; Cels.2.21-22 \\
Daucus carota & RS & & Plin.Nat.25.64 \\
Ficus carica & F & & Plin.Nat.15.19-21; Cels.2.18 \\
Fragaria vesca & F & & Plin.Nat.21.50 \\
Hyoscyamus niger & & JLSR & Plin.Nat.18.16, 18.19 \\
Juglans regia & FJ & & Plin.Nat.15.7, 15.24; Cels.2.18; Virg.G.1.185, 2.65 \\
Lens culinaris & S & & Plin.Nat.18.31; Cels.2.18 \\
Malus pumila/Pyrus communis & F & & Plin.Nat.15.15; Cels.2.24; Virg.G.2.34 \\
Malva spp. & L & & Plin.Nat.20.84; Cels.2.12, 2.20 \\
Olea europaea & FJ & & Plin.Nat.15.1-8; Cels.2.20, 2.24; Virg.G.2.85-86 \\
Piper nigrum & F & & Plin.Nat.12.14 \\
Prunus spinosa & F & & Virg.G.4.145 \\
Punica granatum & F & JP & Plin.Nat.13.34; Cels.2.30, 2.33, 4.12; Col.12.42, 12.46 \\
Rubus fruticosus & F & & Plin.Nat.16.71 \\
Sambucus nigra & F & JLR & Plin.Nat.16.71, 24.35 \\
Solanum sp. & & FJ & Plin.Nat.27.108 \\
Vitis vinifera & FJ & & Plin.Nat.14 passim; Cels.2.18 \\
\hline & & &
\end{tabular}

$L$ leaf, $F$ fruit, $J$ juice or oil, $N$ nut, $P$ peel or rind, $R$ root or bulb, $S$ seeds

Classical authors; Plin. Nat. (Pliny, Naturalis Historia, Bostock and Riley 1855); Cels, Origen, Contra Celsum (Chadwick 1980); Virg., Virgil, Georgics (Kline 2001); Col., Columella, De re rustica (Forster and Heffner 1955) 
Table 2 Overview of the newly introduced and imported food plants recorded at Roman Aelia Mursa (OS-KOS)

\begin{tabular}{lll}
\hline Taxa & Common name & Remains/use \\
\hline Imports & & \\
Ficus carica & Fig & Fruit \\
Olea europaea & Olive & Fruit \\
Oryza cf. sativa & Rice & Cereal \\
Piper nigrum & Black/white pepper & Spice \\
Punica granatum & Pomegranate & Fruit \\
Imported, local cultivation is questioned & & \\
Cucumis cf. melo & Melon & Fruit \\
Introduced and local cultivation plausible & & \\
Allium cf. sativum & Garlic & Vegetable \\
Anethum graveolens & Dill & Herb \\
Cichorium intybus & Chicory & Herb \\
Daucus carota & Carrot & Vegetable \\
Juglans regia & Walnut & Nut \\
Malus/Pyrus sp. & Apple/pear & Fruit \\
Vitis vinifera & Grape & Fruit \\
\hline
\end{tabular}

for medicinal purposes (Table 1). Several of these, such as Anethum graveolens (dill), Daucus carota (carrot), Allium cf. sativum (garlic), Cichorium intybus (chicory) and Cucumis cf. melo (melon) could have been grown in southern Pannonia (Table 2). Thus, kitchen gardens and orchards probably comprised an important component of Roman plant food production in and around Aelia Mursa. Both archaeological and historical records indicate that cities and rural places would have had kitchen gardens for growing food, spices, herbs, medicinal plants, dye plants and perhaps occasionally ornamental flowers (Pagán 2016; van der Veen 2016). Archaeologically these features have not been identified in southern Pannonia, however, evidence of kitchen gardens and orchards has been found in other parts of Europe, including parallel trenches and pits laid out in regular grid patterns (Mattingly 1996; van der Veen 2008; Figueiral et al. 2015; Landry and Moulin 2016; Lodwick 2017a, pp 73, 75, 80).

Of the fruits and nuts, many of these could have been grown in the vicinity of Aelia Mursa, such as Corylus, Juglans and some of the fruits like Physalis alkengengi. Some could also have been brought into southern Pannonia from elsewhere. The presence of grape pips at this time could indicate viticulture in Pannonia, however, the absence of wine presses may indicate that the pips arrived from Dalmatia or further afield in the form of dried fruits or in wine amphorae. There are several references to wine or viticulture in Pannonia (Reed and Ožanić Roguljić 2020), including Roman history by Dio Cassius who stated that the Pannonians "cultivate no olives and produce no wine except to a very slight extent and a wretched quality at that" (49.36, Cary and Foster 1917). Some suggest Pannonian viticulture and the planting of orchards significantly expanded in the 3rd and 4th centuries, particularly around villae rusticae (country villas, often the centre of agricultural estates) (Bulat 2002, p. 46; Gyulai 2010, p. 157; Leleković and Rendić Miočević 2012, p. 280). Thus, at present it is unclear where these grape pips from Aelia Mursa originated from, although their early date may indicate imports.

\section{Imported staples and luxury foods}

In addition to plants that could have grown in southern Pannonia, we also found a range of other foods that, due to climatic constraints, such as frost risk, low average temperatures etc., would not have been grown in southern Pannonia. For example, SU 391 contained numerous Ficus carica (fig) seeds, a few Olea europaea (olive) stones and Punica granatum (pomegranate) seeds. In particular, pomegranate grows best in a semi-arid, mild to sub-tropical climate and so was probably imported into Aelia Mursa. Pomegranate seeds are also rarely found in temperate European contexts during this period (Bakels and Jacomet 2003), suggesting that they were also probably a rare commodity in the town. With the exception of pomegranate perhaps, which can be stored, Mediterranean fruits were probably dried or preserved in some form. The strong evidence of olive/oil, fig and grape/ wine production in Dalmatia (Glicksman 2007) would have provided Pannonia with easy access to such products. This is supported by the finds of type Dr. 6B amphorae from Aelia Mursa and other neighbouring towns that confirm their links to olive oil production centres in the peninsula of Istria, Croatia (Tonc and Filipović 2020). It is also likely that trade followed the Danube southeast to Bulgaria and the Black Sea. In addition, the discovery of Piper nigrum and Oryza cf. sativa which both originate from Asia, shows the extent to which Aelia Mursa was part of the wider Roman food supply 
network. Archaeological and literary evidence suggests that both rice and pepper would have been traded from India, along the Red Sea and into Europe (Thapar 1992; Cappers 2006; van der Veen 2011; van der Veen and Morales 2015; Pliny Naturalis Historia 12.14, Bostock and Riley 1855).

From previously analysed pottery from Aelia Mursa and the surrounding towns it is clear that amphorae and terra sigillata fine pottery from Italy and other regions, such as Spain and Gaul, were being imported from the 1st century AD onwards (Leleković 2018; Nagy and Szakmány 2019; Reed and Ožanić Roguljić 2020; Tonc and Filipović 2020). Although in some cases only a few potsherds have been found we can assume that commodities including wine, olive oil and fish products, such as garum, and possibly defrutum (a concentrated form of grape juice) were being imported there before the colony was established. Whether this was linked with the military has been debated, but there is evidence of Roman settlers in the town from graves dated to the Flavian era (AD 69-96) (Leleković 2020) and also, a range of locally produced imitations of terra sigillata has been found in Pannonia. The first examples of imitation plates, as well as imported terra sigillata, have been found at military sites in southern Pannonia from the time of Claudius (AD 41-54) and are assumed to be products of legionary workshops made for the legionary community (Leleković 2016, 2018). In Aelia Mursa after AD 133, we see a high proportion of locally produced imitation terra sigillata bowls, some of which were probably used for mixing wine. Some of the pottery styles also show evidence of foreign influences mixed with local traditions, with some showing similarities with pottery from southern Gaul and from the east, near the Black Sea (Leleković 2018).

The extraordinary plant assemblage recorded from OSKOS is unique for the southern Danube region. Elsewhere in temperate Europe exotic, possibly luxury foods, have been found at a range of Roman sites including Oedenburg in eastern France (Vandorpe 2010), Vindonissa (Windisch) in Switzerland (Jacomet et al. 2002) and Herculaneum in Italy (Rowan 2017). At the Roman fort and vicus (civilian settlement) of Oedenburg waterlogged plant remains dating to the 1st and 2nd centuries AD yielded a rich and diverse assemblage that contained several imported food plants, including Piper nigrum (black pepper). Plant remains from the pre-legionary and legionary camp phases in Vindonissa (10 BC until 1) revealed a large number of carbonised imports including Punica granatum (pomegranate), Olea europaea (olive), Juglans regia (walnut), Pinus pinea (stone pine), Pistacia vera (pistachio), Prunus persica (peach), P. avium/ cerasus (cherry) and probably Phoenix dactylifera (date) (Jacomet et al. 2002). Other military sites such as the legionary camps of Novaesium (Neuss) or Oberaden, Germany, have several imported foods present including Oryza (rice), P. persica (peach), O. europaea (olive) and Cicer arietinum (chickpea) at Novaesium (Knörzer 1970) and Ficus carica (fig), Piper nigrum (pepper), O. europaea (olive) and Prunus amygdalus (almond) at Oberaden (Kučan 1992). The discovery of imports such as rice and pepper may have been connected to the importing of luxury or high status food items, but their remains are usually found associated with military camps or towns, particularly along the European Limes (frontier) (Zach 2002, pp 104-105; Livarda and van der Veen 2008; Livarda 2011). The contexts range from city sewers to military hospitals and sacrificial pits, highlighting the wide range of uses that even exotic foods such as these would have had in Roman life.

A further site worth mentioning is the archaeobotanical assemblage from the Cardo V sewer at Herculaneum, Italy (AD 70s). Here carbonised and mineralised material, seashells, eggshells, otoliths and fish bones were all recorded. Of the plant remains cereals, pulses, fruits, nuts, herbs and spices were all recovered including P. nigrum (pepper), Coriandrum sativum (coriander), Anethum graveolens (dill) and Phoenix dactylifera (date) (Rowan 2017). The remains showed that in addition to cereals and legumes, the inhabitants of Ins. Or. II who were linked to the sewer system ate a diet based on a limited number of staple foods such as millet, grapes and figs, but supplemented on a frequent basis by over 100 different types of fruits, herbs, fish and shellfish. The similarity in the levels of ubiquity and abundance across all the quadrants indicates that the diet was relatively similar for all individuals and changed little over the ten years of accumulation. The similarities in the composition of these remains and the material recovered from Aelia Mursa suggest that those living in Insula A were also wealthy enough to enjoy a wide and varied diet that included exotics such as rice and black pepper.

In contrast, the contents of a pit at Silchester UK show how an urban population in the new province of Britannia consumed imports including Morus sp. (mulberry), Foeniculum vulgare (fennel) and Prunus domestica (bullace/plum) (Lodwick 2020). This raises the question of the extent to which communities living in new urban centres across the Roman world were able to select which foods they were able to consume, or whether they were reliant on the ebbs and flows of trade connections. In Britain, Orengo and Livarda (2016) suggest that food imports may have been state controlled in the decades following the Claudian invasion, with a strong military influence. However, the distribution of exotic goods beyond the areas of military activity suggest a parallel market economy of private entrepreneurs (Orengo and Livarda 2016). As Livarda (2017) also points out, the dispersal of new foods and flavourings through northwest Europe is strongly associated with the military and with major towns. Thus, significant changes in consumption patterns seem linked to the movement and emergence of new population groups, such as the military or urban populations, 
as well as the ensuing modifications in settlement patterns, economic links and other socio-economic changes (Livarda 2017).

In Aelia Mursa, it is likely that the Roman army played a significant role in the distribution of certain foodstuffs into Pannonia, while the veterans who settled there may have continued their original dietary habits, possibly using army supply networks in southern Pannonia. As it is unclear whether the building on our site, associated with the courtyard and the pits whose contents we studied, was a large residence or possible tavern. We cannot therefore infer the social status of the people who may have consumed some of the foods found there. Who comprised the upper strata of society at Aelia Mursa is also unclear, as there is little epigraphic evidence or signs of any wealthy burials. What we do know is that veterans settled in the town, with skills, money and land and could have been perceived as a provincial 'middle class' (Mayer 2012). Thus, it is likely that a range of different socio-economic factors would have influenced the influx of different and sometimes exotic foods into Aelia Mursa.

\section{Conclusions}

The study of archaeobotanical remains from several pits at the site of Park Kraljice Katarine Kosače, Osijek, provides a tantalising insight into the character of food, farming and trade during a chronologically distinct time period in the early years of the Roman colony of Aelia Mursa. The lack of Iron Age archaeobotanical evidence from Pannonia hinders any direct comparison between the periods. Yet, as with other areas that become incorporated within the Roman empire, there was an influx of new and different food items and edible plants that would have changed local cultivation and culinary practices. In general, the site indicates three regions where food originated, the fertile plains of Pannonia, the Mediterranean (including Dalmatia) and Asia. The identification of more exotic foods, such as rice, pepper and pomegranates raises exciting questions for future research about who may have been consuming these foods? Was there a great demand for such items and what does this say about society and culture at Aelia Mursa?

From the pottery we do know that small quantities of food items were being transported into Aelia Mursa in amphorae before the founding of the colony in AD 133. Imported olive oil, particularly from Istria (Dalmatia), wine and fish products show an early trade of Roman goods to the settlement. Links with the military, especially during the 1 st century AD, probably played a significant role in the uptake of imported goods from the Roman Empire and beyond. How the local towns and military food networks linked is still uncertain, but there was probably a degree of overlap that enabled citizens to obtain certain goods and vice versa. The many trade routes leading into Aelia Mursa make it difficult to determine how the different foods arrived, yet what we see is a thriving cosmopolitan town where exotic food items were available to its inhabitants, as well as a wide range of staple crops, fruits, nuts, herbs and vegetables. Evidence of such a wide variety of foods on the Danubian frontier, including exotics such as rice and black pepper, shows how the towns along the Danube frontier were integrated within the wider Roman food system.

Supplementary Information The online version contains supplementary material available at https://doi.org/10.1007/s00334-021-00858-7.

Acknowledgements A massive thank you to the archaeobotanical community for helping with some of the identifications from this site. In particular, we would like to thank Gill Campbell, Wiebke Kirleis, Dragana Filipovic, Lara González Carretero, Andrew Fairbairn and Dorian Fuller. Many thanks also to Hrvoje Kalafatić for helping with the flotation of the archaeobotanical samples.

Open Access This article is licensed under a Creative Commons Attribution 4.0 International License, which permits use, sharing, adaptation, distribution and reproduction in any medium or format, as long as you give appropriate credit to the original author(s) and the source, provide a link to the Creative Commons licence, and indicate if changes were made. The images or other third party material in this article are included in the article's Creative Commons licence, unless indicated otherwise in a credit line to the material. If material is not included in the article's Creative Commons licence and your intended use is not permitted by statutory regulation or exceeds the permitted use, you will need to obtain permission directly from the copyright holder. To view a copy of this licence, visit http://creativecommons.org/licenses/by/4.0/.

\section{References}

Ash HB (trans.) (1941) Columella, De re rustica (On agriculture) vol 1, books 1-4 (Loeb Classical Library 361), Harvard University Press, Cambridge

Auriemma R (2000) Le anfore del relitto di Grado e il loro contento. Mélanges De L'école Française De Rome Antiquité 112:27-51

Bakels C (1999) Archaeobotanical investigations in the Aisne valley, northern France, from the Neolithic up to the early Middle Ages. Veget Hist Archaeobot 8:71-77

Bakels C, Jacomet S (2003) Access to luxury foods in Central Europe during the Roman period: the archaeobotanical evidence. World Archaeol 34:542-557

Bezeczky T (1996) Amphora inscriptions-legionary supply? Britannia 27:329-336

Bojňanský V, Fargašová A (2007) Atlas of seeds and fruits of Central and East-European flora: the Carpathian Mountains region. Springer, Dordrecht

Bostock J, Riley HT (1855) Pliny the elder, the natural history. Taylor and Francis, London

Britton K, Huntley J (2011) New evidence for the consumption of barley at Romano-British military and civilian sites from the analysis of cereal bran fragments in faecal material. Veget Hist Archaeobot 20:41-52

Brukner O (1981) Rimska keramika u jugoslovenskom delu provincije Donje Panonije. L’Association des Archéologiques de Yougoslavie, Beograd 
Bulat M (2002) Tragovi antičkog vinogradarstva i vinarstva u Slavoniji. Osječki Zbornik 26:45-52

Cappers RTJ (2006) Roman foodprints at Berenike: archaeobotanical evidence of subsistence and trade in the Eastern Desert of Egypt. Cotsen Institute of Archaeology, Los Angeles

Cappers RTJ, Bekker RM, Jans JEA (2006) Digital seed atlas of the Netherlands. Barkhuis Publishing, Eelde

Cary E and Foster HB (1917) Roman history, by Dio Cassius, vol 5, books 46-50. (Loeb Classical Library 82), Harvard University Press, Cambridge

Casteel R (1974) Use of Pacific salmon otoliths for estimating fish size, with a note on the size of late Pleistocene and Pliocene salmonids. Northwest Sci 48:175-179

Cavallo C, Kooistra LI, Dütting MK (2008) Food supply to the Roman army in the Rhine delta in the first century A.D. In: Stallibrass S, Thomas R (eds) Feeding the Roman army: the archaeology of production and supply in the NW Europe. Oxbow Books, Oxford, pp 69-81

Chadwick H (1980) Origen, contra celsum (against Celsus). Cambridge University Press, Cambridge, pp 66-128

Derreumaux M (2005) How to detect fodder and litter? A case study from the Roman site "Le Marais de Dourges", France. Veget Hist Archaeobot 14:373-385

Domić Kunić A (2012) Literary sources before the Marcomannic wars. In: Migotti B (ed) The archaeology of Roman southern Pannonia. (BAR International Series 2393). Archaeopress, Oxford, pp 29-69

Figueiral I, Pomarèdes H, Court-Picon M, Bouby L, Tardy C, Terral J-F (2015) New insights into Mediterranean Gallo-Roman farming: a closer look at archaeological wells in Southern France. Archaeol Anthropol Sci 7:201-233

Forster ES and Heffner EH (1954) Columella, De Re rustica (On agriculture), vol 2, books 5-9. (Loeb Classical Library 407), Harvard University Press, Cambridge

Forster ES and Heffner EH (1955) Columella, De re rustica (On agriculture) vol 3, books 10-12, on trees. (Loeb Classical Library 408), Harvard University Press, Cambridge

Foxhall L (1998) Snapping up the unconsidered trifles: the use of agricultural residues in ancient Greek and Roman farming. Environ Archaeol 1:35-40

Fulford M (1992) Territorial expansion and the Roman empire. World Archaeol 23:294-305

Glicksman K (2007) Olive and wine cultivation in the Roman province of Dalmatia. Histria Antiqua 15:43-50

González Carretero L, Wollstonecroft M, Fuller DQ (2017) A methodological approach to the study of archaeological cereal meals: a case study at Çatalhöyük East (Turkey). Veget Hist Archaeobot 26:415-432

Gyulai F (2010) Archaeobotany in Hungary: Seed, fruit and beverage remains in the Carpathian basin from the Neolithic to the Late Middle Ages. (Archaeolingua 21). Archaeolingua Foundation, Budapest

Havlíček F, Morcinek M (2016) Waste and pollution in the ancient Roman empire. J Landsc Ecol 9:33-49

Jacomet S (2006) Identification of cereal remains from archaeological sites, 2nd edn. IPAS, Basel

Jacomet S, Kučan D, Ritter A et al (2002) Punica granatum L. (pomegranates) from early Roman contexts in Vindonissa (Switzerland). Veget Hist Archaeobot 11:79-92

Jones G (1992) Weed phytosociology and crop husbandry: identifying a contrast between ancient and modern practice. Rev Palaeobot Palynol 73:133-143

Jones G (1998) Distinguishing food from fodder in the archaeobotanical record. Environ Archaeol 1:95-98

Kline AS (2001) Virgil, Georgics, book 2, arboriculture and viticulture. poetryintranslation.com. Accessed 1 Nov 2020
Knörzer KH (1970) Römerzeitliche Pflanzenfunde aus Neuss. (Novaesium 4, Limesforschungen 10). Mann, Berlin

Koloski-Ostrow AO (2015) The archaeology of sanitation in Roman Italy: toilets, sewers, and water systems. University of North Carolina Press, Chapel Hill

Kučan D (1992) Die Pflanzenreste aus dem römischen Militärlager Oberaden. In: Kühlborn J-S, von Schnurbein S (eds) Das Römerlager in Oberaden III: Die Ausgrabungen im nordwestlichen Lagerbereich und weitere Baustellenuntersuchungen der Jahre 1962-1988. (Bodenaltertümer Westfalens 27) Aschendorff, Münster, pp 237-265

Landry C, Moulin B (2016) When GIS goes to the countryside: detecting and interpreting Roman orchards from the 'Grand Palais' (Drôme, France). In: Campana S, Scopigno R, Carpentiero G, Cirillo M (eds) CAA 2015, Keep the revolution going. Proceedings of the 43rd Annual Conference on Computer Applications and Quantitative Methods in Archaeology. Archaeopress, Oxford, pp 499-515

Leleković T (2016) Local imitations of imported fine tablewares from Southern Pannonia; the production of the Flavian and post-Flavian period. Rei Cretariae Romanae Favtorvm Acta 44:609-618

Leleković T (2018) How were imitations of Samian formed? Internet Archaeol. https://doi.org/10.11141/ia.50.18

Leleković T (2020) Elija Mursa: Novo Čitanje Grada. Arheol Rad Raspr 19:77-161

Leleković T, Rendić-Miočević A (2012) Rural settlements. In: Branka M (ed) The archaeology of Roman Southern Pannonia. Archaeopress, Oxford, pp 279-311

Livarda A (2011) Spicing up life in Northwestern Europe: exotic food plant imports in the Roman and medieval world. Veget Hist Archaeobot 20:143-164

Livarda A (2017) Tastes in the Roman provinces: an archaeobotanical approach to socio-cultural change. In: Rudolph KC (ed) Taste and the ancient senses. Routledge, London, pp 179-196

Livarda A, van der Veen M (2008) Social access and dispersal of condiments in North-West Europe from the Roman to the medieval period. Veget Hist Archaeobot 17:201-209

Lodwick L (2017a) Arable farming, plant foods and resources. In: Allen M, Lodwick L, Brindle T, Fulford M, Smith A (eds) The rural economy of Roman Britain. (Britannia Monograph Series 30). Society for the Promotion of Roman Studies, London, pp $11-84$

Lodwick LA (2017b) Agricultural innovations at a late Iron Age oppidum: archaeobotanical evidence for flax, food and fodder from Calleva Atrebatum, UK. Quat Int 460:198-219

Lodwick L (2020) The charred, mineralised and waterlogged plant remains'. In: Fulford M, Clarke A, Durham E, Pankhurst N (eds) Silchester insula IX: the Claudio-Neronian occupation of the Iron Age oppidum. Society for the Promotion of Roman Studies, London, pp 485-514

Mattingly D (1996) First fruit? The olive in the Roman world. In: Shipley G, Salmon J (eds) Human landscapes in classical antiquity: environment and culture. Routledge, London, pp 213-253

Mayer E (2012) The ancient middle classes: urban life and aesthetics in the Roman Empire, 100 BCE-250 CE. Harvard University Press, Cambridge

Mócsy A (1974) Pannonia and upper Moesia: a history of the middle Danube provinces of the Roman Empire. Routledge, London

Nagy AA, Szakmány G (2019) Amphorae as indicators of trade and diet in Cibalae (Pannonia). ArchéoSciences 43-2(2):211-227

Nicholson R, Robinson J, Robinson M, Rowan E (2018) From the waters to the plate to the latrine: fish and seafood from the Cardo V sewer, Herculaneum. J Marit Archaeol 13:263-284

Nikolić T (2018) Flora Croatica database. University of Zagreb, Faculty of science. http://hirc.botanic.hr/fcd, Accessed Jan 2019 
Orengo HA, Livarda A (2016) The seeds of commerce: a network analysis-based approach to the Romano-British transport system. J Archaeol Sci 66:21-35

Pagán VE (2016) Horticulture and the Roman shaping of nature. Oxford handbooks. https://www.oxfordhandbooks.com/view/10. 1093/oxfordhb/9780199935390.001.0001/oxfordhb-9780199935 390-e-78. Accessed 15 Feb 2021

Patterson RT, Wright C, Chang AS et al (2002) Atlas of common squamatological (fish scale) material in coastal British Columbia and an assessment of the utility of various scale types in paleofisheries reconstruction. Palaeontol Electron 4:1-88

Pinterović D (1978) Mursa i njeno područje u antičko doba. Centar za znanstveni rad Jugoslavenske akademije znanosti i umjetnosti, Osijek

Reed K (2016) Archaeobotany in Croatia: an overview. J Archaeol Museum Zagreb 49:7-28

Reed K (2020) Plant remains from Sisak Iron Age settlement. In: Drnić I (ed) Segestica and Siscia a settlement from the beginning of history. Archaeological Museum Zagreb, Zagreb, pp 55-61

Reed K, Leleković T (2019) First evidence of rice (Oryza cf. sativa L.) and black pepper (Piper nigrum) in Roman Mursa, Croatia. Archaeol Anthropol Sci 11:271-278

Reed K, Ožanić Roguljić I (2020) The Roman food system in southern Pannonia (Croatia) From the 1st-4th Century A.D. Open Archaeol 6:38-62

Reed K, Lodwick L, Leleković T, Vulić H (2019) Exploring Roman ritual behaviours through plant remains from Pannonia inferior. Environ Archaeol 24:28-37

Rowan E (2017) Bioarchaeological preservation and non-elite diet in the Bay of Naples: an analysis of the food remains from the Cardo $\mathrm{V}$ sewer at the Roman site of Herculaneum. Environ Archaeol 22:318-336

Šedo O, Knápek R (2016) Barbarian architecture in Moravia during the first centuries AD—building materials, constructions and groundplan layout. Trans Všb-Tech Univ Ostrava Civ Eng Ser 16:71-80

Sidell EJ (1993) A methodology for the identification of archaeological eggshell. Museum Applied Science Center of Archaeology, University of Pennsylvania, Philadelphia

Šoštarić R, Dizdar M, Kušan D, Hršak V, Mareković S (2006) Comparative analysis of plant finds from early Roman graves in Ilok (Cuccium) and Ščitarjevo (Andautonia), Croatia—a contribution to understanding burial rites in Southern Pannonia. Coll Antropol 30:429-436

Šoštarić R, Radović S, Jelinčić Vučković K, Ožanić Roguljić I (2015) Diet at the Roman village of Virovitica Kiškorija, South Croatia. Coll Antropol 39:829-842

Spengler RN III (2019) Dung burning in the archaeobotanical record of West Asia: where are we now? Veget Hist Archaeobot 28:215-227

Starčević S (2010) Karbonizirani biljni ostaci antičkog lokaliteta Osijek-Silos. Unpublished thesis, University of Zagreb, Zagreb

Suic M (1985) Mursensia quaedam. J Archaeol Museum Zagreb 18:57-70
Thapar R (1992) Black gold: South Asia and the Roman maritime trade. South Asia 15:1-27

Tonc A, Filipović S (2020) Only the best olive oil, please: on new amphorae finds from Mursa. Ephemer Napoc 30:273-294

Van der Veen M (1999) The economic value of chaff and straw in arid and temperate zones. Veget Hist Archaeobot 8:211-224

Van der Veen M (2008) Food as embodied material culture: diversity and change in plant food consumption in Roman Britain. J Roman Archaeol 21:83-109

Van der Veen M (2011) Consumption, trade and innovation: exploring the botanical remains from the Roman and Islamic Ports at Quseir al-Qadim. Africa Magna Verlag, Frankfurt

Van der Veen M (2016) Arable farming, horticulture, and food: expansion, innovation, and diversity in Roman Britain. In: Millett M, Revell L, Moore A (eds) The Oxford handbook of Roman Britain. Oxford University Press, Oxford, pp 807-833

Van der Veen M, Morales J (2015) The Roman and Islamic spice trade: new archaeological evidence. J Ethnopharmacol 167:54-63

Van Neer W, Ervynck A, Monsieur P (2010) Fish bones and amphorae: evidence for the production and consumption of salted fish products outside the Mediterranean region. J Roman Archaeol 23:161-195

Van Zwieten C, Cook SR, Voss J, Fulford MG, Pankhurst NA, Barnett CM (2017) Waste disposal in late Iron Age and early Roman Silchester: a geochemical comparison of pits, post holes, ditches and wells in Insula IX. J Archaeol Sci 15:1-7

Vandorpe P (2010) Plant macro remains from the 1st and 2nd Cent. AD in Roman Oedenburg/Biesheim-Kunheim (F): methodological aspects and insights into local nutrition, agricultural practices, import and the natural environment. Unpublished Thesis, Universität Basel, Basel

Vossen I, Groot M (2009) Barley and horses: surplus and demand in the Civitas Batavorum. Theor Roman Archaeol J 2008:85-100

Wesch-Klein G (2007) Recruits and veterans. In: Erdkamp P (ed) A companion to the Roman army. Wiley-Blackwell, London, pp $435-450$

Wilmott T (2001) Birdoswald Roman fort. 1800 years on Hadrian's wall. Tempus, Stroud

Zach B (2002) Vegetable offerings on the Roman sacrificial site in Mainz, Germany-short report on the first results. Veget Hist Archaeobot 11:101-106

Zohary D, Hopf M (2000) Domestication of plants in the old World, 3rd edn. Oxford University Press, Oxford

Publisher's Note Springer Nature remains neutral with regard to jurisdictional claims in published maps and institutional affiliations. 